DOI https://doi.org/10.18551/rjoas.2018-08.30

\title{
THE OPTIMIZATION OF TAX EXTENSION THROUGH PT. POS INDONESIA IN EAST JAVA SAMSAT OFFICE JURISDICTION
}

\author{
Putranto Ridho Tri* \\ Postgraduate School, University of Airlangga, Indonesia \\ E-mail: s2kikunairridho@gmail.com
}

\begin{abstract}
Tax is a very important source of State income, then the tax is levied from Indonesian citizens and becomes one of the obligations that can be imposed billing. This study aims to determine and analyze the behaviour of taxpayers $d$ in the area of East Java and do the analyze efforts to optimize service extension of the Tax through Post Office in region of East Java Province. The results showed that the behaviour of taxpayers in East Java Province is divided into two namely the active taxpayers and non-effective taxpayers. The factors that influence the non-effective taxpayers are taxpayer knowledge factors, behavioural factors of illegal levies, taxpayer income factors, and crowded queuing factors. Efforts to optimize tax extension services through Post Office in East Java Province is to cooperate with Post Office through Post Office counter, Mypos delivery program and Halopos 161.
\end{abstract}

\section{KEY WORDS}

Taxes, post, services, public service.

Tax is very important for development process of a country especially Indonesia, as the development will result in welfare and prosperous life of a nation. In this case, the tax has a role as state income to develop a country. Thus, without any optimum income from taxes, the development of a country would not run well. In order to optimise the income, the role from both government and taxpayer should be synched. The taxpayer must possess enough knowledge about the importance of tax that they one willing to pay. Thus, by knowing the importance of tax, they will obey the regulation of it.

As tax is very important for a nation, the tax is taken from Indonesian citizens and it become mandatory for them as they are forced to do so. Government had invented many ways to make the payment become easier, more intense, and more effective for the service of taxpayer.

One of the companies to help the development of taxes is pt. Pos Indonesia. Pos Indonesia is one of state owned enterprise of Indonesia that runs its business in post service. Now, the form business of pos Indonesia is limited liability Company (known as PT acronym in Indonesia). It is stated in government regulation of Indonesian republic number 5 of 1995. It is about the transformation of pos Indonesia business form from general company to Itd. It aims to provide flexibility and dynamic movement for the company. That is why it will be able to adapt in recent globalisation business and to provide better service for the citizens. Pt pos Indonesia is company who devote its duty in post service and gyro based on the current law.

By using this system, the taxpayer will be easier to finish their payment without taking longer line to get Yearly Tax Collection Letter in tax office. There are 1.027 offices of pos Indonesia across eastern java, the tax payer will have more option to choose the nearest office rather than go into the same place. Moreover, the embosser machine in the offices will help to fasten the process.

In the implementation of services, the Joint Office of Samsat East Java (One-Stop Administration Office) has standard operational procedures and time standard of service which refers to the prevailing laws and regulations. The service process includes registration, assignment, payment, validation, and submission. Improvement of services at Samsat Joint Office is done through the fulfilment of quality which includes ease, speed, mechanism and service procedure, cost transparency and supported by modern technology device that is by developing integrated service system. 
Even though, the cooperation with pos Indonesia is way more efficient and effective. Because, the number of offices are spread across the nation and also in vast area of East Java. It is supported by the experiments done by Hardiningsih \& Yulianawati, it stated that the importance of perception quality towards the willingness to pay the tax as connected with the efficiency and effectiveness of the service itself. The motor vehicle tax is also included in this research.

The veicle taxes are the accumulation of payment that need to be paid by the taxpayer to get the license and other important documents. This become mandatory as the driver must poseessed enough documents to be allowed to drive their vehicle on the road and obey the traffics rule. There are two types of vehicle taxes, yearly tax, and five yearly tax. The number of vehicles and the the state received is increasing through years. But, it does not followed by the awareness of taxpayer importance to fulfill their duty. This is accordance with paper conducted by Susilawati \& Budiartha who stated that the awareness of tax, knowledge, the sanction of tax disobidience, and public accountability have positive impact towards the obidience of taxpayer to pay their responsibility.

\section{METHODS OF RESEARCH}

The study is descriptive qualitative research. The setting of study takes place in PT. Pos Besar Surabaya dan Samsat Jatim, because of taxpaying circulation is very high.

\section{RESULTS AND DISCUSSION}

The Taxpayer Behaviour in Samsat East Java Jurisdiction. The registered taxpayer in taxpayers office consist of two types, they are active and non-effective taxpayers. Active taxpayer is people who run business and registered in the office who still actively report and pay their responsibility both yearly and significant time. in general, the active taxpayer will report their tax status to the office orderly. In the other hand, the non-effective taxpayers report their economic status to unauthorised institutions. According to circular letter of directorat general of taxation number SE-89/PJ/2009 about the instruction for non-effective taxpayers, it is stated that the non-effective taxpayers will be referred as WP NE, they are the taxpayer who do not fulfil their responsibility of both payment and tax collection letter known as SPT in Indonesia and yearly notification letters based on the current taxation law.

Based on in-depth interview, the obedience factors of east java societies in taxation payment are, as follow:

1) Knowledge factor. One of the factors that affect the obedience tax payment is the society knowledge about the procedures and the law of taxpaying in Indonesia. There are many people who are not willing to pay the tax because they had no knowledge of how to fill the tax collection letter because of their lack of knowledge. Moreover, it is caused by the lack of socialisation and tax education by the government.

2) The illegal charges factor. There are many politicians who lack of discipline in taxation reports; it causes many negative impacts to the taxpayer, especially to the middle low social class. The regrets of people are affected by the news of corrupted politicians who steal the public money as it is intended for national development. The amount of illegal charges among civil servants is very high, they are supposed to deliver the tax to the state but they had not. Moreover, there is much collusion found during the investigation of tax payment. The civil servants tend to extorts people who violates the taxation law that will result in illegal charges to cover the truth.

3) The Income Factor. The amount of monthly income from the society also affects the obedience of taxpaying. The more money people get, the more obedience of them to pay and report the tax. Meanwhile, the low class societies tend not to report and pay their tax because of the lack of documents of their current occupation.

4) The long queue factor. In public service implementation, the government, stated in law about public service number 25 of 2009 and according to the Ministry of Administrative and Bureaucratic Reform decision number 63/KEP/M.PAN/7/2003, is stated that the 
foundation, principle, and public service standard to improve the public service quality. The public service standardising must be followed by the synchronised strategies and the success indicators. But, there are still some lacks of vehicle tax transaction found in Samsat office of east java. There are still long queue, thus it will intercept the taxation process. The fixed time schedule of tax payment process will attract more people to pay their responsibility.

The attempt to optimise tax extension service through pt. Pos Indonesia in Samsat east java office jurisdiction:

1. The optimisation of tax extension service through pt. Pos Indonesia in Samsat east java office jurisdiction. To anticipate the taxpayer intercept the payment, there are several options of payment method that are provided by the state. One of them is by paying through post office. Because of the numbers of post offices which are spread across the nation, people will be easier to find the nearest office to accommodate their tax. The Samsat office of east java commences an idea to propose corporation with Pos Indonesia in administrating the vehicle taxes in order to increase the taxpayer willingness. It is supported by signed memorandum of understanding between ministry of central tax, east java Samsat, and Pos Indonesia itself. This cooperation tend to make society will be more willing to administrate their taxes responsibility. The efficiency of payment means more offices and less administrating time, the office could use the advanced technology to help cut time. in accordance with the issue, Provincial Police of East Java add another innovation called Samsat Delivery Post which provide people with three payment method, they are locket, delivery Mypos program and Halopos 161.

2. The obstacles of tax extension service through pt. Pos Indonesia in Samsat east java office jurisdiction. Even though, the cooperation with pos Indonesia is marvellous idea, the socialisation to society is still need to be maximised. Because, people who use post office to pay taxes are still low. By the help of Bhabinkamtibmas, government could tell every people by using the latest technology such as by phone for socialisation, especially in east java. In fact, the socialisation by using Bhabinkamtibmas help is very effective, it could tell people about the new programs of government even in remote are. The society also appreciate this way of socialisation. Because, most people only do administration in their nearest place such as village or its sub. There are several factors that intercept the people's participation which is divided into internal and external factors, as follow:

Internal factor. The internal factors come from the inner problem of the society which come from its individuals and the communities inside them. The society's behaviour, about their participation rate, is determined by sociologies characteristics such age, education level, occupation type, reside time, amount of income, and its participation in development.

External factor. The external factors are caused by the stakeholders, the stakeholders, in this case, is the local/regional government, village governance, RT/RW (neighbourhood/hamlet), consultant, public figure. The stakeholder key is the one who possessed most significant effect to society and had importance position to supervise the program.

\section{CONCLUSION AND SUGGESTIONS}

According to the discussion above, there are some conclusions, as follow:

The tax behaviour in east java province is divided into two which are active and noneffective taxpayer. Then, the factors that influenced non-effective taxpayers are the knowledge, illegal charges, the taxpayer income, and the long queue factors.

The attempt to optimise the tax extension service is by cooperating with pos Indonesia and by developing the payment method through post office locket, delivery Mypos, and Halopos 161 program.

Based on the conclusions above, the researcher would suggest two points as follow:

There must be continuous analysis and evaluation by participation of all committees to hold better program in future life. 
Government should add more people to provide wider socialisation about Online Samsat service and the new payment method in post office. This could be implemented by the help of resort police, sector police, and its elements.

\section{REFERENCES}

1. Alm. J. B. R. Jackson dan M. McKee. (1992). Estimating the Determinants of Taxpayer Compliance with Experimental Data. National Tax Journal. 45 (March). 107-114.

2. Balai Pustaka. (1994). Kamus Besar Bahasa Indonesia. Jakarta: Balai Pustaka.

3. Blanthorne, C. M. (2000). The Role of Opportunity and Beliefs on Tax Evasion: A Structural Equation Analysis. Dissertation. Arizona State University.

4. Brotodihardjo, S. (2011). Pengantar Ilmu Hukum Pajak. Bandung: Refika Aditama.

5. Bungin, B. (2003). Analisis Data Penelitian Kualitatif. Jakarta: PT. Raja Grafindo Persada.

6. Edward III, G. C. (1980). Implementing Public Policy. Washington, D.C: Congressional Quarterly Press.

7. Farokha, D. R., \& Syafi'i, A. (2014). Kualitas Pelayanan Pengiriman Pos Express di PT. Pos Indonesia Cabang Baratajaya Surabaya. Jurnal Online , 58-67.

8. Hamidi. (2010). Metode Penelitian dan Teori Komunikasi. Malang: Universitas Muhammadiyah Malang Press.

9. Hardiningsih, P., \& Yulianawati, N. (2011). Faktor-Faktor yang Mempengaruhi Kemauan Membayar Pajak. Dinamika Keuangan dan Perbankan, Nopember, 126-142.

10. Harinurdin, Erwin. (2009). Perilaku Kepatuhan Wajib Pajak. Bisnis \& Birokrasi, Jurnal Ilmu Administrasi dan Organisasi, Mei-Agustus 2009, hlm. 96-104 Volume 16, Nomor 2.

11. Hutagaol, John. (2007). Perpajakan Isu-isu Kontemporer, Jakarta: Graha Ilmu.

12. Jatmiko, Agus. (2006). Pengaruh Sikap Wajib Pajak pada Pelaksanaan Sanksi Denda, Pelayanan Fiskus, dan Kesadaran Perpajakan Terhadap Kepatuhan Wajib Pajak Studi Empiris Terhadap Wajib Pajak Orang Pribadi di Kota Semarang. Unisversitas Diponegoro: Tesis Megister Akuntansi.

13. Keputusan Menteri Pendayagunaan Aparatur Negara No.63/Kep/M.PAN/7/2003 Tentang Pedoman Umum Penyelenggaraan Pelayanan Publik.

14. Koraag, E. A. (2014). Analisis dan Penerapan Akuntansi Pajak Penghasilan Pasal 25 UU No. 36 Tahun 2008 Pada PT. BPR Celebes. Jurnal EMBA Vo. 2 No. 4 Desember, 471480.

15. Kristanty, N., Khairani, S., \& Fajriana, I. (2015). Pengaruh Pengetahuan Wajib Pajak, Tarif Pajak, dan Penyuluhan Pajak Terhadap Tingkat Kepatuhan Wajib Pajak BAdan di Kantor Pelayanan Pajak Madya Palembang. Jurnal Jurusan Akuntansi 1.

16. Mardiasmo. (2003). Perpajakan Edisi Revisi. Yogyakarta: Andi Offset.

17. Moenir, H. (2000). Manajemen Pelayanan Umum Indonesia. Jakarta: Bumi Aksara.

18. Moleong, L. J. (2001). Metodologi Penelitian Kualitatif. Bandung: Remaja Rosdakarya.

19. Pringgo, Y. (2015). Kualitas Pelayanan Perpanjngan Pajak Melalui Layanan Publik STNK Keliling di Gresik. Kebijakan dan Manajemen Publik, Volume 3, Nomor , Mei-Agustus.

20. Rustiyaningsih, Sri. 2011. Faktor-Faktor yang Mempengaruhi Kepatuhan Wajib Pajak. Widya Warta No. 2 Tahun XXXV,Juli 2011 hal. 44-54.

21. Samsat Propinsi Jawa Timur. (2016). Revolusi Sistem Layanan Terintegrasi Kantor Bersama Samsat Se- Jawa Timur. Jurnal Samsat Propinsi Jawa Timur.

22. Sidik, M. (2001). Optimalisasi Pajak Daerah dan Retribusi Daerah Dalam Rangka Meningkatkan Kemampuan Keuangan Daerah. Artikel Daerah, Vol 1.

23. Soemitro, R. (2007). Dasar-Dasar Hukum Pajak dan Pajak Pendapatan. Bndung: Eresco.

24. Susanti, R. (2016). Evaluasi Manajemen Komunikasi dalam Penerapan Elektronik Filing (e-Filing) di Kantor Pelayanan Pajak Pratama Samarinda. e-Journal Ilmu Komunikasi, 360-373.

25. Susilawati, K. E., \& Budiartha, K. (2013). Pengaruh Kesadaran Wajib Pajak, Pengetahuan Pajak, Sanksi Perpajakan dan Akuntabilitas PElayanan Publik Pada 
Kepatuhan Wajib Pajak Kendaraan Bermotor. E-Jurnal Akuntansi Universitas Udayana 4.2, 345-357.

26. Taufana, V. A. (2014). Kualitas Pelayanan dalam Perspektif Strategi Pelanggan di Bandara Sepinggan, Balikpapan. Pelayanan Publik, Volume 1, Nomor 1, Januari.

27. Uber Silalahi. (2009). Metode Penelitian Sosial. Bandung: Refika Aditama.

28. Undang-Undang Republik Indonesia Nomor 25 Tahun 2009 tentang Pelayanan Publik.

29. Witono, Banu. (2008). Peran Pengetahuan Pajak Pada Kepatuhan Wajib Pajak. Jurnal Akuntansi dan Keuangan, Volume 7, nomor 2, September.

30. Yin, R. K.(1996). Studi Kasus: Desain dan Metode. Jakarta: Raja Grafindo Persada.

31. Zain, M. (2003). Manajemen Perpajakan. Jakarta: PT. Salemba Empat. 